\title{
Interactive methods of training for enhancing communication of IT-professionals
}

\author{
Svitlana Symonenko ${ }^{1, *}$, Nataliia Zaitseva ${ }^{1}$, Viacheslav Osadchyi $^{2}$, and Margaryta Vynogradova $^{1}$ \\ ${ }^{1}$ Dmytro Motornyi Tavria State Agrotechnological University, Department of Foreign Languages, Melitopol, 72312, Ukraine \\ ${ }^{2}$ Bogdan Khmelnitsky Melitopol State Pedagogical University, Department of Informatics and Cybernetics, Melitopol, 72300, Ukraine
}

\begin{abstract}
The paper deals with the issue of enhancing communication of IT-professionals using interactive training methods. It is emphasized that this problem is urgent for IT-education, which has the quickest rate of the content change, formation of new knowledge fields, shift in types and volumes of communication and interaction. Regulations, guides and qualifications frameworks of European countries and Ukraine in terms of requirements to communication of specialists in different fields have been analysed. The concepts of interactive teaching, interactive teaching methods and activities, and their advantages have been studied. It has been noted that interactive methods can be successfully used in teaching general and special subjects for future IT-professionals. Main peculiarities of certain interactive teaching methods have been described. Some practical ideas of the project method, brainstorming, the gamification method, the debate use in the educational process with the focus on the English language at higher educational institutions for enhancing better communication of IT-professionals have been presented. It is emphasized that the meticulous combination of interactive methods and preparation fosters comprehension at the sufficient level both in use of language aspects and in live communication.
\end{abstract}

\section{Introduction}

Modern researchers and practitioners are in the search of the most efficient forms, methods and approaches of the vocational training of specialists in different fields. The search is urgent for IT-education, which has the quickest rate of the content change, formation of new knowledge fields, shift in types and volumes of communication and interaction. The issue of enhancing communication of IT-professionals is even more relative.

Importance of successful communication has been proved by a series of rules, guidelines, procedures, frameworks. The analysis of regulatory acts of European countries has shown that the communicative competence is one of the vital and professional necessities. The European Qualifications Framework for Lifelong Learning includes eight key competences: 1) communication in the native language; 2) communication in a foreign language; 3) mathematical competence and basic competences in science and technology; 4) information competence; 5) ability to learn; 6) social and civic competences; 8) a sense of initiative and entrepreneurship; 9) cultural awareness and expression.

The document emphasizes that all competencies are equal since each competence contributes to the successful life in the knowledge society; competences can be partially matched and combined; many topics can be used in the European Qualifications Framework for Lifelong Learning, as they play a significant role in key competencies: critical thinking, creativity, initiative, problem solving, risk assessment, decision making and constructive management of emotions [1].

The necessity of constant competence improvement and development is confirmed by ISO (the International Organization for Standardization) which has issued ISO 10015:2019 "Quality management - Guidelines for competence management and people development" document where certain crucial modifications in comparison with the ISO 10015:1999 version have been introduced. The authors of the document offer specific guidelines for establishing, implementing, maintaining and improving systems for competence management and people development in order to get positive outcomes of their work. The authors insist that companies, employers or organisations are to encourage people to get or improve competences "by creating learning and training opportunities with circumstances to deploy the outcomes that have been acquired" [2].

National qualifications frameworks of certain European countries (Bulgaria, Germany, Scotland and others) include definite descriptors of communicative competence. Descriptors of 5, 6, 7 and levels of the National Qualifications Framework of Ukraine [3] in the "Communication" category are defined as: interaction, cooperation with a wide range of persons (colleagues, managers, clients) for professional or educational activities; bringing information, ideas, problems, solutions and own experience in the field of professional activity to specialists and non-specialists; ability to formulate a communication strategy effectively;

* Corresponding author: asimonenko@ukr.net 
comprehensive and univocal reporting own conclusions, knowledge and definitions which substantiate them to specialists and non-specialists, particularly to learning people, application of foreign languages in their professional activity; communication in the dialogue mode with broad scientific community and public in a definite field of scientific and/or professional activity. It is obvious, that the contents of communicative competence descriptors have been complicated from one level to another in the document, as specialists are to develop their competences while studying or working.

The PMBOK (A Guide to the Project Management Body of Knowledge, PMBOK Guide) which is considered to be the set of terminology and guidelines for project management [4] emphasizes the importance of communication while working on a project which is in turn an inevitable demand for any high qualified specialist. The guide details three project management processes that are key to successful project communication: planning (developing a communications management plan), execution (management of communications) and control and monitoring (control of communication).

The purpose of the paper is to determine the interactive methodological approaches and forms of training for enhancing communication of ITprofessionals, choose academic disciplines which foster communication of students, and present real examples of interactive activities which have been used.

\section{Interactive methods of training at higher educational institutions}

The most promising and most efficient training forms and methods are interactive forms of educational process organization, technologies and teaching methods at practical classes which can be successfully used in order to form and develop the communicative competence. The practitioner $R$. Knapen [5] defines interactive teaching as "instructing the students in a way they are actively involved with their learning process". The author insists on the existence of numerous ways of such involvement: teacher-student interaction, student-student interaction, audio, visuals, video application, hands-on demonstrations and exercises. The researcher gives the following classification of interactive teaching activities: 1) interactive activities for speech encouraging; 2) individual student activities; 3) student pair activities; 4) student group activities; 5) interactive game activities.

The Ukrainian researcher O. Sichkaruk [6] gives the detailed description of interactive teaching methods in his work: lectures with conversations or discussions, problematic lectures, seminars-discussions, "questionanswer" seminars, discussions with provocative questions, consultations, conversations, round tables, brainstorming, group-specific situations, business games, role-playing and didactic games, business stimulations, projects, and panel exercises.

The use of interactive teaching methods, according to L. Naseikina, initiates such an organization of the educational process, which cannot be carried out in the cognitive process, because interactive teaching starts stimulating the cognitive activity of students and involves each participant in the mental and behavioural activity [7].

It is important to note that interactive learning methods are based on communication, which is not characterized by the exchange of thoughts or knowledge, but on the basis of such exchange the intellectual activity is stimulated. In the same way new knowledge is born, the following abilities are enhanced: to use theoretical knowledge in a particular situation, to combine knowledge from different fields, to take into account the opinion of another person, to work collectively to solve a problem, to take someone else's experience, to take responsibility for the decision made, for the results of their own actions, to manage and obey own ambitions for the sake of the common goal [6].

As professor S. Sysoieva [8] states, the following interactive technologies will be appropriate during practical training in the professional disciplines: the project method, the training, the cooperation in cooperation technology, the method of discussions, and the game method.

Interactive methods are considered by V. Petruk [9] to be helpful in forming the ability to communicate both as a person and a specialist. Students engage in a relationship with each other, resulting in the reproduction of a conflict situation accompanied by natural emotional tension. This leads to increased interest in the learning process. The ability to directly test different situations, promotes further active discussion of a particular problem by students.

As the English language is the humanitarian discipline and suggests communication of education agents even with application of interactive methods and forms, multiple factors should be taken into account when developing a syllabus. Each topic of the course should be looked into in terms of the interactive method which is the most appropriate for the participants, chosen timing, supposed equipment, and the venue. The most efficient language-related interactive methods are presented in Table 1.

In our research we proceed from student massive involvement in communication and creative activities, from timing which requires minimum previous self-work and ninety minutes of English classes at the university.

\section{Application of interactive methods of training for enhancing communication of future IT-professionals}

Having analyzed scientific works, frameworks and guidelines, we have identified the main academic disciplines which foster the development of communication skills for IT-professionals: "Web technologies", "Software development", "Group Dynamics and Communication", "Ukrainian for professional purposes", "English for professional purposes", and "Business English".

In the course of studying the "Group Dynamics and Communication" discipline future IT-professionals aim to form skills of interpersonal communication, developing students' personal and business skills to 
work effectively in partnership with colleagues, in project teams, and in the further professional activity in interaction with customers and users of software products [10]. The discipline is aimed at the development of such competences, defined in 5-6 levels of the National Qualifications Framework of Ukraine in the "Communication" category.

Table 1. Language-related interactive methods.

\begin{tabular}{|c|c|c|c|c|c|}
\hline $\begin{array}{r}\text { Examp- } \\
\text { les }\end{array}$ & $\begin{array}{c}\text { Creati- } \\
\text { ve tasks } \\
\text { (essays, } \\
\text { re- } \\
\text { views) }\end{array}$ & 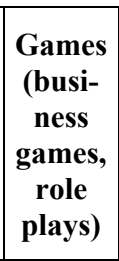 & $\begin{array}{c}\text { Use of } \\
\text { human } \\
\text { resources } \\
\text { (expert } \\
\text { lectures, } \\
\text { tours) }\end{array}$ & $\begin{array}{c}\text { Use of new } \\
\text { material } \\
\text { (instructive } \\
\text { debates, } \\
\text { multimedia } \\
\text { lectures) }\end{array}$ & $\begin{array}{c}\text { Solving } \\
\text { tasks } \\
\text { (brain- } \\
\text { stor- } \\
\text { ming, } \\
\text { case ana- } \\
\text { lysis) }\end{array}$ \\
\hline $\begin{array}{l}\text { Main } \\
\text { agents }\end{array}$ & students & students & $\begin{array}{l}\text { invited } \\
\text { experts, } \\
\text { guides, } \\
\text { teachers }\end{array}$ & $\begin{array}{l}\text { teachers, } \\
\text { lecturers, } \\
\text { invited ex- } \\
\text { perts }\end{array}$ & students \\
\hline Timing & $\begin{array}{c}90 \mathrm{mi}- \\
\text { nutes, } \\
\text { inde- } \\
\text { pendent } \\
\text { learning }\end{array}$ & $\begin{array}{c}90 \mathrm{mi}- \\
\text { nutes, } \\
\text { inde- } \\
\text { pendent } \\
\text { learning }\end{array}$ & $\begin{array}{l}\text { sufficient } \\
\text { timing }\end{array}$ & $\begin{array}{c}90 \text { minutes, } \\
\text { previous in- } \\
\text { dependent } \\
\text { learning }\end{array}$ & $\begin{array}{l}90 \text { minu- } \\
\text { tes }\end{array}$ \\
\hline Venues & $\begin{array}{l}\text { univer- } \\
\text { sity } \\
\text { class- } \\
\text { room }\end{array}$ & $\begin{array}{l}\text { univer- } \\
\text { sity } \\
\text { class- } \\
\text { room }\end{array}$ & $\begin{array}{c}\text { university } \\
\text { classroom } \\
\text { / approp- } \\
\text { riate alter- } \\
\text { native }\end{array}$ & $\begin{array}{c}\text { university } \\
\text { classroom / } \\
\text { lecture hall, } \\
\text { computer } \\
\text { lab }\end{array}$ & $\begin{array}{l}\text { universi- } \\
\text { ty class- } \\
\text { room }\end{array}$ \\
\hline $\begin{array}{c}\text { Support } \\
\text { materials } \\
\text { in Eng- } \\
\text { lish }\end{array}$ & \begin{tabular}{|c|} 
indi- \\
vidual / \\
group \\
tasks, \\
legends, \\
terms \\
\end{tabular} & $\begin{array}{c}\text { legends, } \\
\text { terms, } \\
\text { rules, } \\
\text { timing }\end{array}$ & $\begin{array}{c}\text { leaflets, } \\
\text { brochures, } \\
\text { introduc- } \\
\text { tory hand- } \\
\text { outs }\end{array}$ & \begin{tabular}{|c|} 
lecture \\
notes, pre- \\
sentation \\
files, han- \\
douts, audio \\
/ video files \\
\end{tabular} & $\begin{array}{l}\text { cases, in- } \\
\text { dividual / } \\
\text { group } \\
\text { tasks, } \\
\text { SWOT } \\
\text { schemes } \\
\end{array}$ \\
\hline $\begin{array}{l}\text { Equip- } \\
\text { ment / } \\
\text { devices }\end{array}$ & $\begin{array}{l}\text { appro- } \\
\text { priate } \\
\text { for the } \\
\text { task }\end{array}$ & $\begin{array}{l}\text { appro- } \\
\text { priate } \\
\text { for the } \\
\text { game }\end{array}$ & $\begin{array}{c}\text { wide } \\
\text { screen, } \\
\text { micropho- } \\
\text { ne, com- } \\
\text { puter }\end{array}$ & $\begin{array}{l}\text { wide } \\
\text { screen, mic- } \\
\text { rophone, } \\
\text { computer }\end{array}$ & $\begin{array}{c}\text { white bo- } \\
\text { ard, sta- } \\
\text { tionary }\end{array}$ \\
\hline
\end{tabular}

The purpose of learning the "Ukrainian for professional purposes" discipline [11] is to develop the communicative competence of future IT-specialists, to gain communicative experience, to develop the skills of optimal language behaviour in the professional field: influence on the interlocutor through the skillful use of a variety of linguistic means, mastering the culture of monologue, dialogue and polylogue; perception and reproduction of professional texts, mastering vocabulary and terminology of their speciality, choice of the communicatively justified language.

The "Ukrainian for professional purposes" discipline is aimed at developing such competences, which are defined as common ones in the Tuning project [12]: the ability to put knowledge into practice; ability to communicate, including verbal and written communication in Ukrainian and at least one of the common foreign languages; ability to develop project and program documentation that meets the regulatory documents.

When teaching special disciplines, through which students develop software projects and work as a team
[13; 14], interactive teaching methods are also applicable. A set of methods can be applied, namely: the project method, the cooperation method (small groups), brainstorming, the case method, and the debate.

At the very beginning of the course, teachers of the department of foreign languages at Dmytro Motornyi Tavria State Agrotechnological University give students of the "Computer Science" speciality commonly known reasons for learning English. At the beginning of the second term of studying English students participate in a debate on the same matter. The goals of the debate are:

1) comparing students' perspective on English learning necessity at the beginning of the course and after six months of being students in their major;

2) generating effective critical thinking;

3) comprehending significant and complex ideas about participants' future profession;

4) stimulating team work and developing negotiation skills;

5) training participants how to articulate own position regarding learning English.

At the first stage, two teams are imposed the attitude by their teacher (either willingness or neglecting learning a foreign language). After the panel discussion, when both teams are given scores for each reason they represent and prove right as a group each student may shift their ground and join the counterpart team. The third stage includes individual acts of speech when each speaker represents their real vision of English necessity in the modern world, for their personal and professional prospect.

The scores are awarded either, especially when speaker's personal experience in communicating with English speakers, using English for task solving or resource exploration is provided. From previous experience it is obvious that "pro"-group is always a victorious team. In spite of fair pointing to difficulties in language acquisition (like a lack of free time because of English home assignments, advisable money investment in educational resources, different personal educability levels, different backgrounds of school English courses), the winner usually scores over their rivals due to numerous arguments about learning English as an integral part of the prospective career path as an ITspecialist.

The project method is based on the idea that reflects the essence of the concept of "project", its pragmatic focus on the result that can be obtained when solving a particular problem. The result can be seen, comprehended, applied in the field. The solution of the problem becomes the nature of the project activity [8].

The main feature and advantage in the process of forming the communicative competence of future ITprofessionals is that the final result should be a real product, but not an imaginary project. Students' efforts should be directed towards collection, analysis, processing of real information, taking into account the real situation in the country or in a certain industry, social sphere, based on the existing rules, laws and regulations [6].

The practical use of the project method in the process of forming the communicative competence of future IT- 
professionals in the study of professional disciplines can be explained by the example of the "Web-technology" discipline concepts:

1. Idea: development, self-development of the communicative competence of future IT-specialists.

2. Goals:

- to learn how to use knowledge in a practical activity that simulates future professional activity;

- to acquire new professional competences or to develop already existing professional competences of a student, in particular, the communicative competence;

- to achieve high results in educational research work by performing project activities;

- to develop teamwork skills.

3. Content: covers the theory and practice of creating online resources.

4. Main groups of tasks:

- educational tasks - mastering the technology of project activity, theoretical knowledge of the discipline and the ability to apply it in practical activities, learning to find the best ways to create a project, to master communicative skills;

- scientific tasks - developing the ability to analyze scientific and methodological sources, Internet sources, the ability to summarize scientific facts and advanced pedagogical experience;

- methodological tasks - developing the ability to design project development activities, plan and design their project activities, apply communication skills in teamwork.

5. General requirements for the project:

1) independent and authentic work;

2) relevance of the project, i.e. its relevance to the current state of information technology;

3) external attractiveness and performance accuracy;

4) conformity of the development tools with the discipline studied;

5) content-richness (appropriate volume and quality of materials);

6) following the specific requirements of the project (the requirements for the webpage construction, functionality, content volume and quality must be met).

6. Possible project topics: "Development of a personal website", "Development of a thematic site", "Development of the website of the department", "Development of the site of the university", "Creating a blog", "Development of an online store" and others.

7. Competences of students to be improved: personalintellectual, communicative, creative, social, information-communication, and research competences.

8 . Forms of organization of students: simple project one student; complex project - 2-3 students.

9. The role of a teacher in project-based learning: compiles project topics, advises students, defines reporting forms, assessment criteria, delivery time, technical design, and project defense forms.

10. Project defence forms: presentations, reports, demonstrations.

It is necessary to note, that in order to be successful, all communication components in projects must function effectively and communication barriers must be overcome to the maximum. Developing a communication plan can be one way of overcoming communication barriers and building successful communication.

The American researcher S. Rajkumar [15] proposes four steps for effective communication between a project manager, a project team, and stakeholders while working on the project. According to the author, the first step is to determine the communication requirements, i.e. to determine the information required for each project participant, to calculate the number of communication channels and to determine the communication time. The second step is to determine $5 \mathrm{~W}$ (Why, What, When, Where, Who, and $1 \mathrm{H}$ (How)), in other words, to identify the recipients of the messages (Who), information types (What), communication timeline (When), environment (Where), causes of communication (Why), and communication channels (How). The third step is to identify and take into account the environmental factors of the organization that influence the communication process, such as organizational culture and structure, project management information system, etc. The last but not least important step is to determine peculiarities of organizational processes that affect communication, such as standards and policies unique to the organization, organizational instructions, work instructions and criteria for evaluating the effectiveness of others.

The scientist A. Zub [16] insists that a communication plan is an integral part of the project plan. It may include a plan for collecting information that identifies the sources of information and how to obtain it; an information sharing plan that identifies consumers of information and how information is delivered; a detailed description of each document to be received or transmitted, including the format, content, level of detail and definitions used; plan for putting into operation various types of communications; methods of updating and improving the communication plan. The communication plan can be formalized and detailed depending on the needs of the project.

Within the project there is a need for different types of communication: internal (within the project team) and external (with the management of the customer, external organizations, etc.) communication; formal (reports, requests, meetings) and informal messages; written and oral communication; vertical and horizontal communication.

All the mentioned above states that student projects can and should be interactive and professionally managed in order to be successful. Let us consider the project which is based on both communicating with different agents and activities with the PMBOK Guide.

The PMBOK Guide may become a very effective means to improve students' communicative skills and to enhance the research activity within an interactive project - planning by students their research activity for an academic year. The participants of a study group (the undergraduates and postgraduates who major in Computer Science at Dmytro Motornyi Tavria State Agrotechnological University) were familiarized with the PMBOK Guide at the end of the spring term. They were given group and individual assignments for the 
summer holiday. As a group, 8 participants should have interacted and cooperated to perform the following tasks:

1) to negotiate in order to come to an agreement with their group supervisor and with each other about the schedule of group sessions acceptable for everyone;

2) to find online 10 conferences and paper calls, to contact the organization committees (in writing or online) and to make sure that every participant's research field corresponds with the search results and can be represented as a conference report or a thesis;

3) to collaborate in order to plan in advance the summarizing discussion (its form, venue, participants, technical support and handouts provided) at the end of the academic year.

The individual assignment supposed a researcher to establish correspondence with a potential scientific supervisor and to represent their written approval of student's future line of investigation and timing.

The outcomes of the mentioned above interactive project at the end of the winter term have been:

- having successfully planned definite group and individual activities due to the latest practices in project management;

- training of peer communication within the study group; - teaching students to address themselves in adequate manner to experts in their field of research and official committee representatives and to maintain academic correspondence both in writing and orally (online);

- academic and official English language acquisition through acquiring language patterns;

- providing students' awareness of communication strategy transferability between Academic English and Business English.

In current project activities presented above, the communication competence is being effectively enhanced. Therefore, we consider the project method to be the most appropriate and adequate method to correspond the specifics of ICT. Moreover, in the project activity, future IT-professionals are able to fully demonstrate communication skills and develop communication skills, especially in the case of combination of the project method with other interactive methods.

The issues of building successful communication and overcoming communication barriers are key issues in the modern world of employment, where workers and employers can play different roles, change these roles, learn new methods and technologies, and communicate effectively regardless of their new roles and functions. Moreover, they should be able to build relationships of any type and within any hierarchical organization model. Modern higher education curricula should include special courses, modules, seminars, lectures and psychological training to prepare future professionals to work in different circumstances for effective communication, to form readiness to overcome various communication barriers, to develop communication strategies to be ready to function effectively in the workplace.

Both in the course of project work and in the process of solving software development problems the collaborative learning method can be used. It is the method aimed at developing certain skills and competences, mastering concepts, academic and professional knowledge provided by the curriculum, or organizing project activities with further discussion. In order to build the communicative competence of future IT-professionals, it is important that this method is focused on group goals and the success of the entire group, which can only be achieved through the independent work of each member in simple interaction with other members of the same group when working on a problem, a question to be studied [8].

Brainstorming is a common practice in the software industry. In the concept of software project management, brainstorming is the first stage in the development of a software product. Its purpose during training sessions is to activate students' communicative and intellectual activity, which aims at expressing ideas for solving a specific problem, proposing ways to solve a certain problem, as well as freeing from the inertia of thinking, overcoming stereotypes in solving a creative problem, accumulating ideas for solving the proposed problem [6].

Brainstorming is widely used within planning research and vocational training events jointly with students. Along with bright ideas for projects engaging equally instructors and students, student view and ideas matter for improving learning and educational resources and tools.

The examples of realization of such spontaneously contributed ideas are improvement of the department websites. At the beginning of 2018, students of Dmytro Motornyi Tavria State Agrotechnological University majoring in Computer Science were asked to skim through newly adopted corporate design of the department of foreign languages website within the university domain and to generate ideas and ways to increase traffic to the webpage of the Department of Foreign Languages [17]. In the evaluation session several attracting visitor website headers have been developed and some menu items have been deleted. The content selection strategy has also emerged from that brainstorming session and nowadays it tends to be less entertaining and more progressive.

The website of the Informatics and Cybernetics Department within the domain of Bogdan Khmelnitsky Melitopol State Pedagogical University [18] has also been created considering the results of brainstorming session. The ideas of using the template with automated scroll to given anchor when clicking on a header or a link and also displaying smart popups connected to the department instructors photos presenting brief information about their positions and scientific interests have arisen from collaboration with students majoring in Computer Technology and Digital Design.

Consequently, combining and improving mutual brainstorming ideas have ensured easy-to-use website navigation, attracting content and present-day layout, preferred by students themselves.

The case method is widely used in vocational education because situational exercises (a real description of the situation that occurred in professional practice) offered to students can be created to master the profession. The situation (case) can be offered for 
student analysis as a task for independent individual work, and can be used in the organization of group classroom work [6]. For example, when studying the "Web technology" discipline students are given a situational exercise about breaking an institution's website, detailing the structure of the site, technology of its creation, symptoms of problems (in which browser, at what stage of work, under what conditions, and what just happened). Having processed the data reported by the teacher, students are divided into groups or work individually to hypothesize about the cause of the failure and the means to remedy it. The results of the work of groups and strategies from individual students are evaluated by the instructor. It is concluded who was closest to the correct definition of the problem and ways of solving it, what was wrong and what was right. In this way, situational exercise can be triggered by brainstorming or discussion. However, students can practically demonstrate computer-assisted troubleshooting.

The rival method regarding student interest is the gamification method because it is one of the most powerful motivation factors for learning languages. Business English provides lots of opportunities to combine professionally based and business-like situations within one role game. Postgraduate students of the 'Computer Science' speciality of Dmytro Motornyi Tavria State Agrotechnological University were given legends to dramatize a job interview.

The main task was to discuss professional skills required by the job. The main challenge was that according to the legends both the employer (a big financial consortium) representative and candidates (ITprofessionals with different personal and professional background) had some issues to conceal.

The English teacher was a participant of the game either, but their legend was "a trade union representative", who was monitoring that neither party's rights were violated and that inadequate, inappropriate questions (about candidates' private life, health issues, financial background) were not asked. In the case of facing a difficulty with the usage of English or discussing a candidate's hard and soft skills, the trade union representative could be appealed to for a brief prompt. The teacher did not support any of the parties and did not articulate their evaluation of the process. Student improvisation and spontaneity in the legend development and extension were welcome unless they violate the game rules.

The participants had to communicate in adequate manner (politely, business-like and completely honest). Nevertheless, each party had to reveal the other's concealed facts (gaps in candidates' CVs; disadvantages of the workplace) through questioning and to make a reasonable decision. The employer's representative had to choose the most suitable supervisor for their IT-team, and each of the candidates had to give arguments for their willingness or refusal to take the job.

The outcomes of the game include students' progress in:

- consolidation of oral and written speech token and IT terminology;
- including learned language patterns for Business English in spontaneous speech;

- improving skills in analyzing oral speech and applicant papers, deducing language pattern meaning from context, inferring and predicting;

- raising awareness of work ethic and business communication norms;

- increasing student motivation to be engaged in successive role games.

Having implemented several interactive methods from the methods described above the Business English Essentials for Software Engineers guide for senior students of IT-specialities has been composed. The guide is intended for extending reading, writing, and speaking skills with the accent on job-related situations: searching for a job, applying for a job, job interviews etc. Every unit has an active vocabulary list, an authentic text, numerous exercises, samples of documents, infographics and useful phrases for discussions. The information for the course book is retrieved and adapted from modern Internet resources.

In addition to the guide a distant learning course on Business English for IT-specialists [19] and a course on English for Computer Science students [20] have been developed. Every unit comprises a vocabulary list, an authentic text on the corresponding topic, useful grammar references, videos and audios with tasks, vocabulary and grammar tests. The most used questions are Drag and Drop into Text, Embedded Answers (Cloze), Matching, Multiple Choice, Selecting Missing Words, Short Answer, Description, and Essay. The course includes the compulsory self-testing unit to check student outcomes at the end of the term. In order to facilitate communication in English, a chat has been created in the course in which it is possible to ask questions, leave comments, answer questions, and share useful information All the students who participated in interactive class activities have proved the comprehension level of course material ( $76 \%$ average).

\section{Conclusions}

The interactive methods are inevitable in modern education: when meticulously prearranged, their implementation provides background for student's confident participating, supports developing and enhancing available skills and abilities (both academic and professional), delivers opportunities for students to follow up independently in their personal selfdevelopment and vocational mastering. The most preferred by students interactive methods (the project method, gamification, brainstorming) are the most effective since they are positively perceived, allow students to contribute most of the input into the method implementation terms, encourage students' improvisation and spontaneity. As our research shows, the thorough selection of interactive methods and preparation for English classes fosters comprehension at the sufficient level both in use of language aspects and in live communication. The prospects for future research can be development of the methodology of application of interactive teaching methods for enhancing communication of IT-professionals at higher educational 
institutions and experimental examination of the methodology.

\section{References}

1. Recommendation on Key Competences for Lifelong Learning adopted by the European Parliament and the Council in December. (Official Journal of the European Union, 2006), https://eurlex.europa.eu/LexUriServ/LexUriServ.do?uri=OJ:L: 2006:394:0010:0018:en:PDF. Accessed 08 January 2020

2. ISO 10015:2019 Quality management - Guidelines for competence management and people development. (International Organization for Standardization, 2019), https://www.iso.org/obp/ui/\#iso:std:iso:10015:ed2:v1:en. Accessed 20 December 2019

3. Pro zatverdzhennia Natsyonalnoii ramky kvalifikatsii (On National Qualifications Framework). (Legislation of Ukraine, 2020), https://zakon0.rada.gov.ua/laws/show/1341-2011\%D0\%BF?lang=uk. Accessed 29 October 2019

4. PMI. A guide to the project management body of knowledge. (Project Management Institute, Newtown Square, Pennsylvania, 2017), pp. 82-86

5. R. Knapen, 20 interactive teaching activities for in the interactive classroom (2018), https://www.bookwidgets.com/blog/2018/06/20interactive-teaching-activities-for-in-the-interactiveclassroom. Accessed 20 December 2019

6. O. Sichkaruk, Interaktyvni metody navchannya $u$ vyshhij shkoli (Interactive teaching methods at higher school). (Takson, Kyiv, 2006), pp. 19-20

7. L. Naseikina, Realizatsiya kompetentnostnogo podhoda pri formirovanii professionalnoznachimyih lichnostnyih kachestv studentovprogrammistov (The implementation of the competence-based approach to the formation of professionally significant personal qualities of software engineering students). Bulletin of OSU 9(158), 34-41 (2013)

8. S. Sysoieva, Interaktivni tekhnologii navchannia doroslykh (Interactive technology for adult learning). (EKMO, Kyiv, 2011), pp. 120-121

9. V. Petruk, Dissertation, Vinnitsa National Technical University, 2008

10. P. Lozynskyi, Vikoristannia kompiuternoi programy Skype na zaniattiah inozemnoi movy (Application of Skype at foreign language classes). Bulletin of Ivan Franko Zhytomyr State University 1, 230-235 (2015)

11. T. Andreieva, Ukrainska mova (za profesiinym spriamuvanniam) (Ukrainian for professional purposes). (Kyiv, 2012)

12. J. González, R. Wagenaar, Universities' contribution to the Bologna process. (Publicaciones de la Universidad de Deusto, Bilbao, 2008), pp. 2732
13. V. Kruglyk, V. Osadchyi, Formirovanie kompetentnosti $\mathrm{v}$ oblasti programmirovaniya $\mathrm{u}$ budushchikh inzhenerov programmistov (Developing Competency in Programming among Future Software Engineers). Integration of Education 23, 587-606 (2019). doi:10.15507/19919468.097.023.201904.587-606

14. V. Osadchyi, V. Kruhlyk, H. Chemerys, K. Osadcha, in ICTERI'2019: Integration, Harmonization and Knowledge Transfer, ed. by V. Ermolayev, F. Mallet et al. 15th Int. Conf. ICTERI 2019, Kherson, Ukraine, June 12-15, 2019. Vol. II, p. 17-28

15. S. Rajkumar, in $P M I ®$ Research Conference: Defining the Future of Project Management, Washington, DC, 2010

16. A. Zub, Upravlenie proektami (Project management). (Yurayt Publishing House, Moscow, 2018), pp. 280-285

17. Kafedra inozemnykh mov (Department of foreign languages) (2020), http://www.tsatu.edu.ua/im/. Accessed 05 January 2020

18. Visokoyakisna vyshcha osvita IT fakhivtsia u Melitopoli (High-quality higher education for ITspecialists in Melitopol) (2020), http://inf.mdpu.org.ua/. Accessed 05 January 2020

19. Business English for IT-specialists course (2020), http://nip.tsatu.edu.ua/course/view.php?id=1507. Accessed 05 January 2020

20. English for Computer Science students (2020), http://nip.tsatu.edu.ua/course/view.php?id=1507. Accessed 05 January 2020 